\title{
The Israeli Challenge of Cognitive Influencing
}

DOI: $10.37458 /$ nstf.22.1-2.4

\section{Ephraim Lapid*}

The German philosopher Friedrich Hegel determined that a person's core substance does not derive from that person's deeds but from his or her projection in the cognition of the other, where "objective reality" is neutralized and the perceived reality of cognition rules. Carl von Clausewitz said that suppressing the enemy's combat spirit is no less effective than actually killing his soldiers. He stressed that it is necessary to complement kinetic combat with actions that affect the enemy's cognition.

Ever since the early 2000 s, especially in this era of global terror, we have repeatedly realized that the battlefield is not where the outcomes of a military confrontation are determined. The results of an operation or war are no longer determined by the number of casualties or targets hit but by the image imprinted in the public cognition in Israel and worldwide. More than many other countries, Israel is situated in a region pervaded by terrorist confrontations and has devised over the years methods to sway the cognition of

* Dr. Ephraim Lapid, deputy head of the Europe Institute at Bar Ilan University lectures on national security topics at the University. He was formerly a senior military intelligence officer and the IDF Spokesman. 
Israeli society, terror organizations, and the international community.

The type of confrontation that has largely replaced classical wars between sovereign states and regular armies has unique characteristics springing from the nature and conduct of terrorist organizations. In the sphere of cognition, terror organizations, ignoring any moral or legal rules, deliberately perpetrate various acts of violence to coerce governments into changing their policies. Two prominent terror organizations are at the focus of this threat to Israel: Hezbollah and Hamas.

The struggle against terror organizations occurs on three fronts simultaneously: In the field, where security forces clash with terror organizations and individual perpetrators; on the political front, where both sides strive to secure the support of the international community and the Muslim world; and lastly, on the cognitive front, where both sides use a variety of methods and means to instill their stands and perceptions in relevant target audiences. The three fronts influence and complement each other. Each of their achievements or failures affects, sometimes crucially, the managing of the other fronts. The results of each confrontation between Israel and a terrorist adversary become engraved in the cogniton of the Israeli population and the populations of Gaza or Lebanon, but no less so in the global public opinion and among decision-makers worldwide.

Military, public, and academic debates have been going on for years about the significance of the cognitive component in the operational success of military action. There was a need to implement creative thinking and diplomacy in the various public media to structure the required cognitive reality. People determine their views about the results of a confrontation based on the data flow 
on the social networks, internet sites, television, radio, and the printed press (by order of accessibility to the consumers). Israel and Hamas have both been investing creative thought and means to maintain their ability to influence.

In the past, we used the term "information". Nowadays we speak about a cognitive campaign. Academic writing about modern strategy frequently uses the term "new wars", describing the current battlefield as "a combat between people", in contrast to past combat means used in armored, aerial, and naval encounters. "New wars" is a recent term that has replaced the previous "limited confrontation" and "asymmetric war". Hezbollah and Hamas both operate amidst the civilian populations that surround them, using civilians as a human shield to hide seniors and conceal infrastructures and rocket launchers. They take advantage of the IDF's offensive response in that civilian environment to keep delegitimizing the IDF in the eyes of the world (a tank against a mosque, fire near a hospital - both hiding places for terrorist commanders, infrastructures and rockets).

A cognitive campaign should be comprehensive, involve all the relevant state institutions and authorities, such as the military, security, legal, economic, and diplomatic bodies, and under close intelligence supervision. The media efforts made by the IDF, especially on the social networks the enemy is attentive to, are one example of an activity that has enormous operational potential for the State of Israel. This overt effort has a considerable potential to influence and turn around opinions, whether of decision-makers or the public at large. Acting on the overt media requires understanding and proficiency in the psychology of the masses and an ability to analyze and target specific audiences.

Modes of action: 
- Three-stage action. Similar to other combat operations, an information operation also comprises a preparatory, simultaneous, and retroactive stage. This involves preparing diverse information materials during the planning stage, issuing ongoing reports while a military operation is underway, and summing up the data and lessons learned after reaching an arrangement for cessation of hostilities.

- Cognitive-influencing actions require the participation of elements from the government, the military, local authorities, non-profit organizations, students, and Jewish and Israeli communities abroad.

- Fake news: Develop an ability to refute fake news immediately as they appear but do not react to trivial details to avoid being perceived as lacking initiative and irresponsible.

Be prepared to "put out fires". Mishaps are likely to occur in almost every confrontation (such as fires, disaster). A skilled reaction team must be familiar with the facts and react before a mishap leads to confrontation.

- Avoid superfluous details. Present the main data required to understand the results of an action in an appealing visual way. Creative graphic design is the best appetizer to taking in the information.

- Employ an experienced professional staff. It is crucially important the people involved in information be highly experienced.

- Restore the national information System. Israel's national information has been divided for years between different bodies and has suffered a lack of coordination and guidance. In 2007, after the Second Lebanon War, an attempt was made to improve the situation by setting up a National Information body within the Prime Minister's Office, which worked successfully for several years.

- $\quad$ Direct Israeli information at the Arab world. In the past few years, the impact of information in Arabic 
initiated by the IDF Spokesman unit, the prime minister's office and the foreign ministry has grown noticeably.

Two types of efforts associated with the culinary world stand out in the process of information dissemination during hostilities. One regards dissemination of preliminary information, much like "fast food" eaten on the spot but not necessarily satisfying. The other resembles a "gourmet meal" - thorough briefs and detailed written material, intended to reinforce the messages sent through various influence channels.

In summary, the intelligence services play a highly significant role in the struggle for cognitive raising. In the past, intelligence work focused on obtaining enemy secrets, interpreting them, and distributing them to the decision makers. Nowadays, it is not sufficient to know the enemy's secrets. Information and intelligence products must be put to use in the struggle for cognitive raising. Intelligence gathering is no longer just part of the secret war. It has become an integral factor in the effort to acquire materials from various sources to expose and refute enemy accusations and efforts to disseminate fake news.

Information is crucial to national security, as the past decade's anti-terror operations have repeatedly proven. Information efforts must be a central part of the efforts the government makes in such events along with the military effort, the effort to protect the rear (the civil front) and the international political effort. The traditional Pavlovian reaction after every operation claims that "the information has failed". This claim is often unfounded. Israel no longer play the role of David in the historical battle of David and Goliath. We can no longer blame the problematic situation on lack of resources only. The cynical world wishes to see Israel weakened. We are better off strong and especially wise, rather than just right. 


$$
\begin{aligned}
& \text { สิ } \\
& \text { สูป }
\end{aligned}
$$

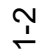

$$
\begin{aligned}
& \text { 山ै } \\
& 5 \\
& \text { Ш } \\
& \text { 足 } \\
& \text { 文 }
\end{aligned}
$$

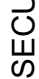

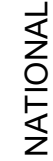

